\title{
Targeting "bad" B cells in multiple sclerosis
}

\section{Could laquinimod be part of the armamentarium?}

\section{OPEN}

Thomas G. Forsthuber, $\mathrm{MD}, \mathrm{PhD}$

Olaf Stuve, MD, PhD

Correspondence to Dr. Forsthuber:

thomas.forsthuber@utsa.edu

Neurol Neuroimmunol Neuroinflamm 2016;3:e283; doi: 10.1212/ NXI.0000000000000283

See article

Laquinimod is an orally available quinoline 3carboxamide derivative drug studied in phase II and III clinical trials for relapsing-remitting multiple sclerosis (RRMS), systemic lupus erythematosus, and Crohn disease. Laquinimod has shown promise in RRMS clinical trials, ${ }^{1,2}$ and identifying the mechanism underlying its disease-modifying effects could help target it to the patient population where it would be most effective. Studies in experimental autoimmune encephalomyelitis (EAE) models of multiple sclerosis (MS) have suggested that the drug may ameliorate disease by modulating innate and adaptive immune responses, for example via effects on macrophages/monocytes, dendritic cells (DCs), and T-helper (Th) cells. ${ }^{3-5}$ However, its key effector mechanisms and the cellular targets by which the drug ameliorates disease are still not fully resolved. The article by Varrin-Doyer et al. $^{6}$ in this issue of Neurology ${ }^{\circledR}$ Neuroimmunology \& Neuroinflammation sheds new light on this question and provides important insights that could be relevant for the treatment of MS. In elegant experiments, Varrin-Doyer et al. provide convincing evidence that treatment with laquinimod strongly ameliorates disease in 2 models of recombinant myelin oligodendrocyte glycoprotein (MOG)-induced EAE and spontaneous EAE in mice transgenic for a T-cell receptor specific for MOG3555 peptide and a MOG-specific immunoglobulin $\mathrm{H}$ chain knock-in $(2 \mathrm{D} 2 \times \mathrm{Th}$ mice). In both of these models, the authors show that laquinimod treatment prevented the development of T-follicular-helper (Tfh) cells and decreased the production of MOG-specific immunoglobulin $\mathrm{G}$ antibodies. Interestingly, in a spontaneous model of EAE, associated with the formation of meningeal follicle-like structures that are populated by $\mathrm{B}$ and $\mathrm{T}$ cells, ${ }^{7}$ laquinimod therapy reduced the number and the size of these cellular aggregates.

It is important to note that disease induced by recombinant MOG in this model is critically dependent on $\mathrm{B}$ cells and myelin antigen uptake via the B-cell receptor and presentation to autoimmune CD4+ T cells. In contrast, simultaneous expression of a MOG- specific T-cell receptor and MOG-specific immunoglobulin $\mathrm{H}$ chain in the $2 \mathrm{D} 2 \times \mathrm{Th}$ mice leads to spontaneous disease replicating human neuromyelitis optica (NMO), and MOG-specific autoantibodies are pathognomonic in this condition. Thus, the results by Varrin-Doyer et al. show the efficacy of laquinimod in B-cell-driven EAE disease models with CNS pathology induced by different pathogenic effector mechanisms.

The question to be asked then is how relevant is this observation for MS? B cells, one should recall, have moved in and out of the center of attention in the etiology of MS since the discovery of oligoclonal bands in the CSF of patients with MS in the 1940s. Obviously, a key role of B cells is the production of antibodies, and, consequently, detection of autoantibodies for diagnostic and prognostic purposes in patients with MS has been researched for many years. More recently, other functions of B cells have attracted attention that could account for their potential role in the etiology and pathogenesis of MS, which center on their antigen presentation and $\mathrm{T}$ cell-activating properties, regulatory function (i.e., interleukin-10-producing regulatory $\mathrm{B}$ cells), and the enigmatic role of meningeal B-cell follicles. The rapid clinical improvement observed after B-cell depletion with rituximab ${ }^{8}$ and ocrelizumab 9 in patients with MS supports the concept that B-cell functions besides antibody production may be important for modulating disease in RRMS, in particular since anti-CD20 therapy does not deplete long-living antibody-producing plasma cells, and therefore should have less of an immediate effect on potentially pathogenic autoantibodies. In contrast, the pathogenic role of autoantibodies in NMO is better established and supported by animal studies, such as spontaneous disease development in 2D2 $\times$ Th transgenic mice. ${ }^{7}$

While the net effect of laquinimod in this study resulted in the impairment of the B-cell effector responses in the tested disease models, the logical next question is if this was due to direct effects of the drug on B cells, or whether this was indirectly achieved by modulating other cells. Along these lines, laquinimod inhibited

From the Department of Biology (T.G.F.), University of Texas at San Antonio; Department of Neurology and Neurotherapeutics (O.S.), University of Texas Southwestern Medical Center; and Neurology Section (O.S.), VA North Texas Health Care System, Medical Service, Dallas.

Funding information and disclosures are provided at the end of the editorial. Go to Neurology.org/nn for full disclosure forms.

This is an open access article distributed under the terms of the Creative Commons Attribution-NonCommercial-NoDerivatives License 4.0 (CC BY-NC-ND), which permits downloading and sharing the work provided it is properly cited. The work cannot be changed in any way or used commercially. 
the development of Tfh cells, conceivably by modulating the function of follicular DCs. Induction of regulatory $\mathrm{T}$ cells may have contributed to the Tfh defect. Evidence for a direct effect of laquinimod on B cells comes from in vitro studies with human B cells, ${ }^{10}$ and the study by Varrin-Doyer et al. adds to this view by showing that laquinimod-treated B cells were impaired in their ability to induce Tfh cells upon adoptive transfer to B-cell-deficient mice. This effect did not seem to be the result of impaired antigen presentation, but conceivably, downregulation of CD40 on laquinimod treated B cells could point to a mechanism.

As stated above, a potentially important finding was the decrease in meningeal B-cell aggregates noticed in EAE mice treated with laquinimod. Meningeal B-cell follicles may very well contribute to disease etiology in patients with progressive MS, and identification of the molecular mechanisms underlying the laquinimod effect on B-cell follicles could have added beneficial effects in patients. While B-cell follicles have yet to be demonstrated in patients with primary progressive MS (PPMS), ocrelizumab showed a benefit in patients with this disease phenotype, ${ }^{11}$ and a phase II clinical trial with laquinimod is ongoing (clinicaltrials.gov/ct2/ show/NCT02284568).

The study by Varrin-Doyer et al. paves the way for more detailed studies determining the molecular targets of laquinimod in CNS demyelinating diseases, in particular in the context of $\mathrm{B}$ cells and progressive disease. The observation of a key role for B cells in the treatment effect of laquinimod brought forth by these studies is consistent with the key contributions of B cells to the etiology of MS and may open an additional alley besides anti-CD20 treatment as to how to interfere with the pathogenic effects of this lymphocyte subset in RRMS and PPMS.

\section{STUDY FUNDING}

No targeted funding reported.

\section{DISCLOSURE}

T. Forsthuber has served on the editorial boards of Clinical Immunology, Journal of Immunology, PLoS One, and Frontiers in Multiple Sclerosis and Neuroimmunology and Immunotherapy; and has received research support from the National MS Society. O. Stuve received travel funding from Teva Pharmaceuticals; is on the editorial board for JAMA Neurology,
Therapeutic Advances in Neurologic Disorders, Clinical and Experimental Immunology, and MS Journal; consulted for Huron Navigant Consulting; received research support from Teva Pharmaceuticals, Opexa Therapeutics, US Department of Veterans Affairs, and Biomedical Laboratory Research and Development; has served on scientific advisory boards for Pfizer and Sanofi-Aventis; has served on the editorial boards of JAMA Neurology, Therapeutic Advances in Neurological Disorders, Clinical and Experimental Immunology, and MS Journal; and has received research support from Teva Pharmaceuticals Opexa Therapeutics and the Department of Veterans Affairs. Go to Neurology.org/nn for full disclosure forms.

\section{REFERENCES}

1. Comi G, Jeffery D, Kappos L, et al. Placebo-controlled trial of oral laquinimod for multiple sclerosis. $\mathrm{N}$ Engl J Med 2012;366:1000-1009.

2. Vollmer TL, Sorensen PS, Selmaj K, et al. A randomized placebo-controlled phase III trial of oral laquinimod for multiple sclerosis. J Neurol 2014;261:773-783.

3. Schulze-Topphoff U, Shetty A, Varrin-Doyer M, et al. Laquinimod, a quinoline-3-carboxamide, induces type II myeloid cells that modulate central nervous system autoimmunity. PLoS One 2012;7:e33797.

4. Jolivel V, Luessi F, Masri J, et al. Modulation of dendritic cell properties by laquinimod as a mechanism for modulating multiple sclerosis. Brain 2013;136:10481066.

5. Yang JS, Xu LY, Xiao BG, Hedlund G, Link H. Laquinimod (ABR-215062) suppresses the development of experimental autoimmune encephalomyelitis, modulates the Th1/Th2 balance and induces the Th3 cytokine TGF-beta in Lewis rats. J Neuroimmunol 2004;156:3-9.

6. Varrin-Doyer M, Pekarek KL, Spencer CM, et al. Laquinimod treatment of spontaneous EAE reduces Tfh, B cell aggregates, and disease progression. Neurol Neuroimmunol Neuroinflamm 2016:3:e272. doi: 10.1212/NXI.0000000000000272.

7. Bettelli E, Baeten D, Jager A, Sobel RA, Kuchroo VK. Myelin oligodendrocyte glycoprotein-specific T and B cells cooperate to induce a Devic-like disease in mice. J Clin Invest 2006;116:2393-2402.

8. Hauser SL, Waubant E, Arnold DL, et al. B-cell depletion with rituximab in relapsing-remitting multiple sclerosis. $\mathrm{N}$ Engl J Med 2008;358:676-688.

9. Kappos L, Li D, Calabresi PA, et al. Ocrelizumab in relapsing-remitting multiple sclerosis: a phase 2, randomised, placebo-controlled, multicentre trial. Lancet 2011;378: 1779-1787.

10. Toubi E, Nussbaum S, Staun-Ram E, et al. Laquinimod modulates $\mathrm{B}$ cells and their regulatory effects on $\mathrm{T}$ cells in Multiple Sclerosis. J Neuroimmunol 2012;251:45-54.

11. Ocrelizumab Use in Primary Progressive Multiple Sclerosis (PPMS). Barcelona: ECTRIMS; 2015. 


\title{
Neurology \\ Neuroimmunology \& Neuroinflammation
}

\author{
Targeting "bad" B cells in multiple sclerosis: Could laquinimod be part of the \\ armamentarium? \\ Thomas G. Forsthuber and Olaf Stuve \\ Neurol Neuroimmunol Neuroinflamm 2016;3; \\ DOI 10.1212/NXI.0000000000000283
}

This information is current as of September 21, 2016

\section{Updated Information \& Services}

References

Subspecialty Collections

Permissions \& Licensing

Reprints including high resolution figures, can be found at: http://nn.neurology.org/content/3/5/e283.full.html

This article cites 10 articles, 1 of which you can access for free at: http://nn.neurology.org/content/3/5/e283.full.html\#\#ref-list-1

This article, along with others on similar topics, appears in the following collection(s):

Multiple sclerosis

http://nn.neurology.org//cgi/collection/multiple_sclerosis

Information about reproducing this article in parts (figures,tables) or in its entirety can be found online at:

http://nn.neurology.org/misc/about.xhtml\#permissions

Information about ordering reprints can be found online: http://nn.neurology.org/misc/addir.xhtml\#reprintsus

Neurol Neuroimmunol Neuroinflamm is an official journal of the American Academy of Neurology.

Published since April 2014, it is an open-access, online-only, continuous publication journal. Copyright $\odot$ 2016 American Academy of Neurology. All rights reserved. Online ISSN: 2332-7812.

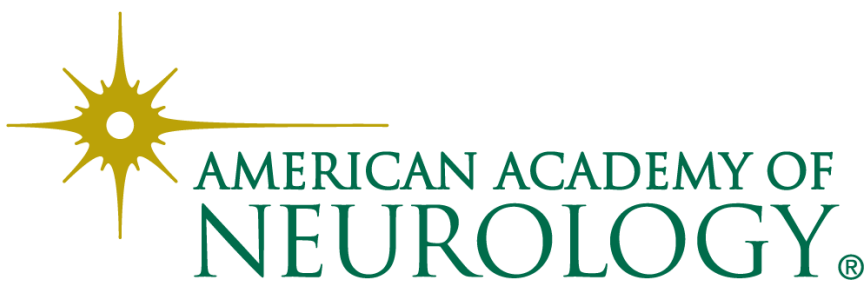

